\title{
PSYCHE
}

\begin{tabular}{lll}
\hline Vol. 75 & March, I968 & No. I \\
\hline
\end{tabular}

\section{STUDIES ON NEOTROPICAL \\ POMPILIDAE (HYMENOPTERA) \\ IV. EXAMPLES OF DUAL SEX-LIMITED \\ MIMICRY IN CHIRODAMUS ${ }^{1}$}

\author{
By Howard E. Evans \\ Museum of Comparative Zoology
}

\begin{abstract}
INTRODUCTION
Taxonomy is considered a branch of biology, but it might equally well be regarded as a special kind of detective work. One gathers evidence from diverse sources and tries to build a case for the natural classification of a group. On occasion the result is a "hung jury": the evidence does not fit together into a convincing picture. On occasion - but all too rarely - the evidence leads on into broader problems than originally supposed and provides new insights into biological phenomena. I believe that the present investigation is such a case, and I shall present the evidence much as it came to me. Much of it is circumstantial or even suppositional, but not any more so than is often true in taxonomy. The conclusion - that certain South American spider wasps of the genus Chirodamus have males that are Batesian mimics of one complex of wasps and females that are Müllerian mimics of a very different complex - is so far as I know a novel facet of the mimicry problem.
\end{abstract}

The story begins in 1945, when Nathan Banks described a new genus of pompilid wasps from South America, calling it Amerocnemis. He based this on one female, described as $A$. bequaerti, and several males which he did not describe at that time. In his review of the South American Pepsinae in 1946, Banks described three species from the male sex: argentinica, brasiliensis, and longula. In 1957, Townes

\footnotetext{
${ }^{1}$ Acknowledgment is made to the William Morton Wheeler Fund of the Museum of Comparative Zoology for assuming the cost of the colored plate and of publication.

Manuscript received by the editor December 5, 1967.
} 
recognized bequaerti as a species of Priocnessus and correctly placed Amerocnemis in the synonymy of that genus. The three "male" species, although relatively large and striking, have remained unassigned generically and unassociated with any female. Banks noted that these species all have what he called "markings suggestive of Batazonus", by which he meant that their color pattern suggested several species of Poecilopompilus (= "Batazonus" of Banks, more properly Batozonus) in the subfamily Pompilinae. The Poecilopompilus in question (and the "male Amerocnemis") all in fact belong to a very large mimetic complex of tropical America, centering around quite a number of social Vespidae sharing a more or less common yellow, ferruginous, and black pattern (Figs. I-9).

Although males of these species have been accumulating in the collections of the Museum of Comparative Zoology over the past few years, I found no females to match them. Then, in the summer of 1966, Charles C. Porter of Harvard University returned from Argentina with an excellent series of Banks' "Amerocnemis" argentinica, all taken January through April at Horco Molle, Tucumán (Fig. 9). The variation in this series was considerable, and led me to my initial conclusion, that Banks' brasiliensis was no more than a rather dark extreme of the same species (the Poecilopompilus of eastern Brazil also tend to be darker). Comparison of the genitalia of the types of Banks' two species has confirmed this conclusion.

At the same locality, Porter collected an undescribed female Chirodamus having a rather narrow front and reduced body pubescence but otherwise typical of this genus. Like many Chirodamus, this was a black wasp with bright orange wings, a member of a large complex of aposematically colored "Pepsis-mimics" which ranges all the way from the western United States to Patagonia (Fig. IO). This complex includes Pompilidae of several different genera (Figs.

Explanation of Plate 1

Fig. 1. Cerceris sp., 우 (Sphecidae). Fig. 2. "Mischocyttarus alfkenii zikanii Richards, ㅇ (Vespidae). Fig. 3. Poecilopompilus polistoides Smith, ㅇ (Pompilidae). Fig. 4. Colpotrochia sp. 1, ô (Ichneumonidae). Fig. 5. Dolichomitus zonatus Cresson (subsp.), ㅇ (Ichneumonidae). Fig. 6. Colpo-

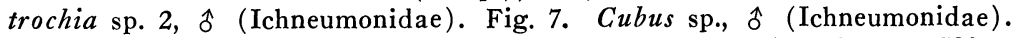
Fig. 8. Ephialtes bazani Blanchard, o (Ichneumonidae). Fig. 9. Chirodamus argentinicus Banks, ô (Pompilidae). Fig. 10. C. argentinicus Banks, 우 (Pompilidae). Fig. 11. Priocnemella omissa Banks, ㅇ (Pompilidae). Fig. 12. Chirodamus longulus Banks, \& (Pompilidae). Fig. 13. Priocnemioides unifasciatus luteicornis Lepeletier, o (Pompilidae). Fig. 14. Chirodamus longulus Banks, ô (Pompilidae). Fig. 15. Apoica thoracica Buysson, ㅇ (Vespidae). 


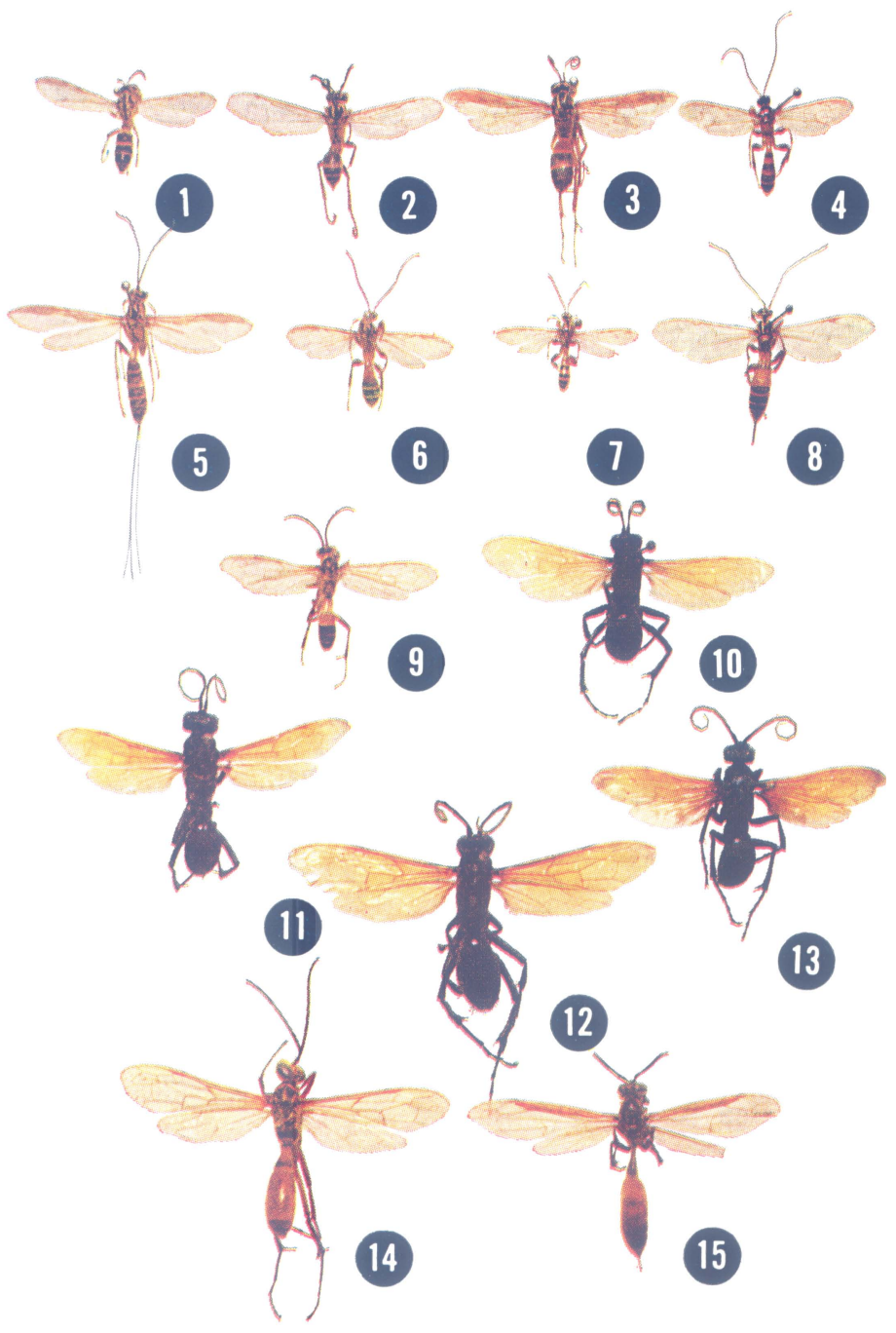

Evans - Mimicry in Chirodamus 
I I, I3) as well as Ichneumonidae, Diptera of at least two families, several aegeriid moths, and at least one staphylinid beetle and one grasshopper. Members of this complex vary from quite small to some of the largest Hymenoptera known: apparently the black and orange coloration is effective at several size levels. The females of $P$ epsis and other Pompilidae form the Müllerian center around which the many non-stinging members are arrayed as presumably Batesian mimics (including, of course, the males of these same Pompilidae). This complex includes no social wasps that I am aware of.

The resemblance of argentinica males to those of the unknown Chirodamus (on structural features, certainly not on color), led me to look into the third "male Amerocnemis", longula Banks. This larger species was described from the Rio Purus, in western Brazil, and we have an excellent series collected at Quincemil, Peru, by Luis Peña (Fig. I4). To my satisfaction, I found several specimens of an orange-winged Chirodamus taken by Peña at the same time and place and showing many structural resemblances to the male longula (Fig. I2). In this case the female belonged to the same mimetic complex as the presumed female of argentinica, but the male was too large and too brown to be a possible mimic of the same complex as the male argentinica. However, a scanning of the social wasps of this area, including those taken by Peña at the same locality, reveals that there are several possible models (Fig. I5).

A more detailed study of the structure of the pompilid wasps in question has convinced me that these sex associations are correct and that these species properly belong in the widely distributed, protean genus Chirodamus (in the sense of Townes, 1957). Having reached this decision, it was natural for me to look for other species which might also be "dual mimics". I immediately considered the possibility that pentodon Arlé, from eastern Brazil, might represent another example. This species was actually described in the genus Batozonus, but Arlé's excellent figures make it clear that it is a close relative of argentinicus. In March, I966, Henry and Marjorie Townes collected a fine series of this species along with tawny-winged females belonging to a species which has been called vitreus Fox, and I am convinced that this is a third example of dual mimicry, although in this case the wing color of the female is less intensely orange than in most Pepsis and other aposematically colored spider wasps. I have also discovered two additional species, each represented by a single male, which belong to this complex. These are described below. 
A search for possible examples in other genera has also been productive. For example, the male of Austrochares mexicanus Dreisbach is colored strikingly like Poecilopompilus flavopictus and several social wasps; the female, however, is black with an orange abdomen, a common pattern among wasps and probably aposematic (Evans, 1966). The South American Austrochares autrani (Holmberg) is similarly colored. In both cases the sexes have only recently been associated.

It should be added that there are many cases in which the females are aposematically colored or colored so as to resemble Mutillidae or other powerful stingers, but in most such cases the males are simply black and non-mimetic (e.g., Psorthaspis formosa, Aporus idris; Evans, I966). Also, in nearly all other cases of $P$ epsis mimicry, both sexes share the bright orange wings and dark bodies (in Pepsis, Hemipepsis, Priocnemioides, many Chirodamus, Cryptocheilus, etc.). In a number of cases certain species are Pepsis-mimics within the range of orange-winged Pepsis, but non-mimetic, black wasps outside of the range of the model (e.g., Cryptocheilus idoneum; Townes, 1957).

Dual mimicry appears to be a relatively uncommon phenomenon in the Pompilidae, though doubtless more cases will be discovered. Henry Townes has pointed out to me that a generally similar sexual dimorphism in color occurs in many ichneumon wasps, particularly in the subfamily Ichneumoninae, and in certain Scoliidae in which there are large patches of orange in the females while the males lack the orange and are black with yellow banding. Such instances also suggest that each sex has evolved to copy a different aposematic or mimetic pattern, although the resemblance is of a more generalized type than that described here. The possible origin of such color dimorphism is discussd following a more detailed description of dual mimicry in Chirodamus.

\section{DESCRIPTION OF DUAL MIMICRY IN CHIRODAMUS}

It should first of all be pointed out that many species of Chirodamus have black or blue-black bodies and bright orange wings in both sexes, for example, the western North American pyrrhomelas Walker and the South American fidanzae Holmberg. Other species, in many cases those occurring in areas where orange-winged Pepsis are rare or absent, are black with black or hyaline wings (e.g., $C$. fortis Cresson, in eastern United States, and $C$. kingii Haliday, the type species, in Patagonia). Members of the argentinicus group range from northern Argentina to Brazil and Ecuador, an area in which both orange-winged Pepsis and conspicuously banded social Vespidae and their various mimics are very common. 
Since the case of $C$. argentinicus is best documented, I will discuss it first and at greatest length. Charles C. Porter collected the first known female of this species at Horco Molle, Argentina, and the Townes took a second female at this same locality. This is a locality in which a very similarly colored Priocnemioides, $P$. unifasciatus luteicornis (Lepeletier) is common and in which other orange-winged species of Chirodamus, Priocnemioides, and other genera occur. As mentioned earlier, this is a very common Müllerian mimetic pattern, with members occurring all the way from the western half of the United States to central Argentina and Chile. It includes pompilids of other tribes and subfamilies (e.g., Notocyphus, Abernessia) as well as an assortment of Diptera, Lepidoptera, Coleoptera, and Orthoptera. In this instance, the resemblance of the female $C$. argentinicus to that of $P$. unifasciatus luteicornis is especially close; they are similar in size and in all details of coloration of the body, wings and antennae (Figs. IO, 13). It seems probable that luteicornis is the major model in this area.

Charles Porter collected males flying in the vegetation along with several species of Ichneumonidae which resemble it closely. Certain of these are species which produce an odor unpleasant to humans and presumably serving in defense against avian predators (e.g., Ephialtes bazani, Fig. 8). In other localities this same color pattern was repeated but included other Hymenoptera. For example, at Alto la Vina, in Jujuy, it was found to include the pompilid Poecilopompilus polistoides (Fig. 3), a species of the sphecid genus Cerceris (Fig. I), and the social wasp Mischocyttarus alfkenii zikanii Richards (Fig. 2). Certain species of social wasps of the genera Polybia and Stelopolybia also share essentially this same color pattern, as do certain Diptera, day-flying moths, and even leafhoppers. It is impossible to define this mimetic complex fully at this time or to list with certainty its components in any given area. The following list includes species taken by Porter in localities in northwestern Argentina in fundamentally similar habitats and sufficiently alike to deceive a human collector.

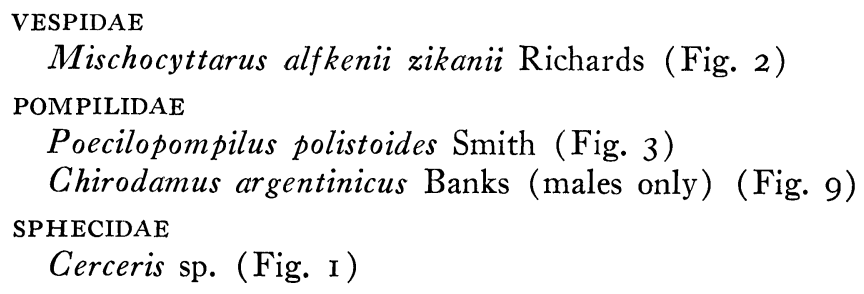


ICHNEUMONIDAE

Carinodes sp.

Colpotrochia sp. I (Fig. 4)

Colpotrochia sp. 2 (Fig. 6)

Cubus sp. (Fig. 7)

Dolichomitus zonatus Cresson (subsp.) (Fig. 5)

Ephialtes bazani Blanchard (Fig. 8)

Ichneumoninae (Genus and Species?)

Metopius sp.

Theronia lineata Fabricius

Porter has supplied me with notes on the behavior and occurrence of some of these wasps. The male Chirodamus were taken along trails in wet forest, usually flying in undergrowth about $\mathrm{I}-4$ feet off the ground. He notes that of all members of this complex they have the fastest flight, "usually appearing only as a furtive yellow streak against a dark background of foliage". Theronia, Carinodes, and an unidentified member of the Ichneumoninae also flew here, although somewhat more slowly, while Ephialtes bazani, a species with a disagreeable odor, occurred here but was quite sluggish in its flight. The species of Colpotrochia tended to occur in more open situations, and one of them was one of the most abundant insects at Horco Molle, sometimes swarming in high grass in sunshine but being scarcer in the forest. Since workers of the various social wasps tend to forage in a variety of situations, they may of course provide a unifying factor for wasps of somewhat diverse modes of life. All of these wasps are essentially inhabitants of vegetation somewhat above the ground, in contrast to the majority of "Pepsis-mimics", which spend much time walking over the ground in the search for terrestrial spiders.

In this instance we know that the male Chirodamus fly in the same situations as other, similarly colored wasps, but in the other cases of supposed dual mimicry the evidence is more indirect. The female $C$. longulus (Fig. I2) is very similar in appearance to that of $C$. argentinicus (Fig. IO) and to Priocnemioides unifasciatus luteicornis (Fig. 13). Luis Peña also took Priocnemella omissa Banks (Fig. I I) at the same locality as a series of longulus, and there are of course species of Pepsis of basically this same coloration in this same area. There seems no question that the female longulus belongs to this same complex of "Pepsis mimics".

The male of longulus is patterned with brownish-ferruginous and fuscous, with dull yellowish markings on the head and thorax; the abdomen is weakly banded with fuscous but lacks yellow markings 
(Fig. I4). Its larger size and quite different coloration indicate that it belongs to a different mimetic complex than the male argentinicus. Luis Peña collected, at the same time and place as a series of longulus, a long series of Apoica thoracica Buysson, a social vespid known to be an aggressive stinger (Fig. I5). The specks of $A$ poica have enlarged ocelli and are nocturnal or crepuscular. It should be noted that the ocelli of Chirodamus longulus are also unusually large for a pompilid, suggesting that this species, so similar to Apoica thoracica in size and coloration, may also be crepuscular. Other social Vespidae of similar size and coloration occurring within the range of longulus (but presumably diurnal) include Polistes occipitalis Ducke and Mischocyttarus tomentosus Zikán. These species lack the infuscation along the anterior border of the fore wing occurring in Apoica, and in this respect are more like Chirodamus longulus.

In the case of Chirodamus vitreus, from eastern Brazil, the females appear to be imperfect "Pepsis mimics" since the wings are only faintly tinged with orange. It is worth noting that some of the species of Priocnemioides occurring here also have the wings either weakly suffused with orange or only partially of this color (brasiliensis, coeruleus); indeed the wings of $P$. unifasciatus luteicornis are notably darker in eastern Brazil than in Argentina. Perhaps these species represent a subcomplex of Müllerian mimics characteristic of this area. The male vitreus is basically similar in color to that of argentinicus and is doubtless a member of much the same complex, centering around certain social wasps. It is of generally darker color than argentinicus, some individuals being mostly black, but it should be noted that many groups of wasps have species of generally darker coloration in this region, e.g., Poecilopompilus costatus (Pompilidae) and Polybia sericea (a social vespid). We have a great deal to learn about the composition of various mimetic complexes in the neotropics, and it seems certain that final clarification will involve across-theboard studies of several different families of wasps and, in fact, several orders of insects.

The two new species described below from males only, imitator (from Ecuador) and impensus (from Paraguay) are both large, pale wasps, and although the two are not closely related I suggest that the model for both may be the large, aggressive social wasp Apoica pallida, the range of which includes both countries. The male of imitator has enlarged ocelli, like that of longulus and like the species of Apoica, so it may well be crepuscular. I predict that the females 
of these two species will be found to have black bodies, partially orange antennae, and largely orange wings: that is, that they will be "Pepsis mimics" like those of other members of this species group.

One is, of course, curious to know what selection pressures produced males that are Batesian mimics of social wasps and females that are Müllerian "Pepsis-mimics". As pointed out earlier, the males, in their irregular searching flights, remain mostly well above the ground, chiefly in herbs and bushes that may contain workers of social wasps. At the same time the females spend the greater part of their time on the ground searching for spiders, in the same habitat as the various orange-winged species of Pepsis, Priocnemioides, and other genera. It is true that orange wings like those of the females seem to serve the males of most related wasps perfectly well: presumably birds and lizards learn to avoid this color and do not discriminate between the sexes. Evidently the males of these species of Chirodamus have achieved a still more effective level of protection by resembling certain common social wasps. It is probable that other cases of marked color dimorphism, such as in the genus Austrochares and in certain Scoliidae and Ichneumonidae, as mentioned earlier, reflect the fact that males and females spend the greater part of their time in slightly different situations, such that selection has favored a different mimetic pattern.

In complexes such as these the distinctions between Batesian and Müllerian mimicry and between the latter and generalized aposematic patterns are obviously unclear. I have spoken of male Pepsis as Batesian elements in their complex, but the fact is that both sexes of at least some species of Pepsis have a characteristic odor, and this odor may well be repellant to predators. Similarly, the odor of the slow-flying ichneumon Ephialtes may serve to reinforce its mimicry of social wasps - a bird that "forgets" the mimetic pattern is reminded, not by a sting, but by a chemical stimulus. It is probable that many male and non-stinging female Hymenoptera are not fully palatable. Furthermore, many males, when seized, undergo movements of the abdomen suggestive of stinging, and in several groups the genitalia or apical sternite have evolved into a pointed "pseudosting", often capable of pricking but never supplied with poison glands. That "palatability" is no simple phenomenon has been further shown by Brower et al (1967), who found that some races of the monarch butterfly are actually palatable "automimics" of distasteful members of the same species that have fed as larvae on poisonous species of milkweeds. 
In the case of Chirodamus argentinicus and its allies, and the mimetic complexes involved, it is obvious enough that we know little of such matters. Indeed, the fact that to our eyes these wasps resemble one another in color and form does not necessarily mean that they look alike to predators and thereby gain protection. However, no one who has spent much time in the neotropics is likely to question the existence of large complexes of wasps and wasp-like insects that share common color patterns and flight behavior. Experimental work such as that of Brower and Brower (1965) on drone flies as mimics of honeybees lends support to the belief that such mimicry is effective against vertebrate predators. Nevertheless, each case is different and must be weighed on its own merits. The amount of work waiting to be done in this field is frightening. For the moment, the concept of dual mimicry may at least serve a useful purpose in helping to associate the sexes in certain refractory sections of the Pompilidae and other groups.

\section{TAXONOMIC TREATMENT}

A brief description of Chirodamus was provided by Townes ( I957, p. II), who also figured the wings of a North American species (his Fig. I). As Townes pointed out, some of the diversity in this genus involves characters elsewhere given generic value. For the present, however, it seems best to use the generic name in a broad sense, using the category of species-group for the more distinctive complexes of species, thus avoiding nomenclatorial changes that can be no more than tentative until the group has been studied from a world point-of-view. The species treated here are considered to constitute the argentinicus species-group. Members of this group have departed considerably from the usual robust, hairy form of the genus, but in my opinion there is no structural discontinuity sufficient to justify generic or even subgeneric status for this group. For the record, I have included a drawing of the male genitalia of $C$. fidanzae (Holmberg) (Fig. 2I), an Argentinian species of robust body form, densely hairy and otherwise similar to more "typical" Chirodamus. Although the claws of the male are bifid, it is otherwise very unlike argentinicus and its allies and most certainly not a member of this group. The drawings demonstrate the basic similarity of the genitalia, however: the basal hookets are double, there are large, hairy lobes at the base of the digitus, the digitus itself is bilobed, and the parameres bear a series of stout pegs. This supports the belief that the argentinicus group should be included in Chirodamus despite superficial differences. 


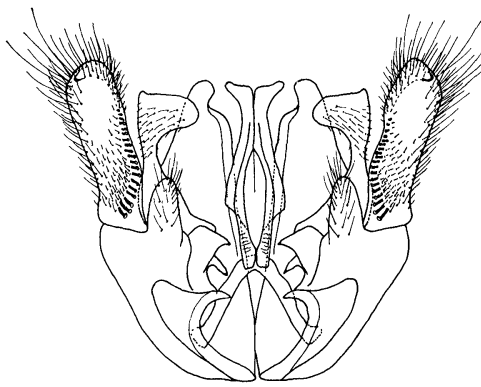

16

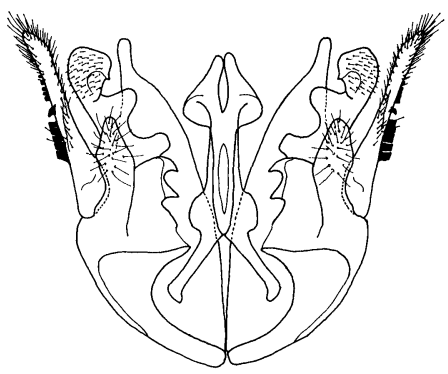

18

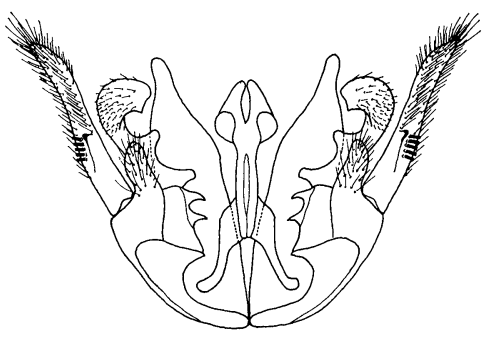

20

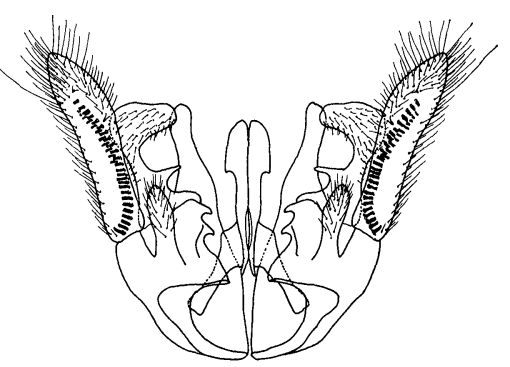

17

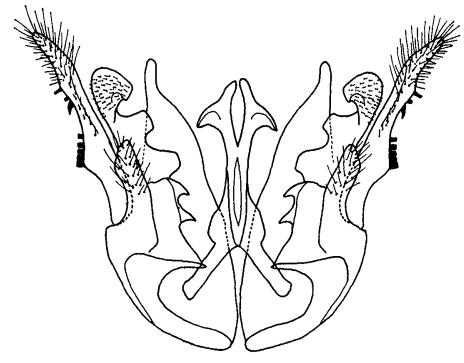

19

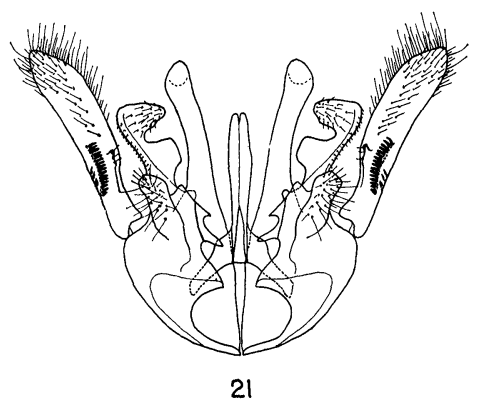

Fig. 16-21. Male genitalia of Chirodamus spp., ventral aspect. Fig. 16. C. imitator n. sp., holotype. Fig. 17. C. longulus Banks. Fig. 18. C. impensus n. sp., holotype. Fig. 19. C. argentinicus Banks. Fig. 20. C. vitreus Fox. Fig. 21. C. fidanzae Holmberg. 
Characters of the argentinicus species-group.-Antennae, legs, and body relatively slender for the genus, the abdomen of the male especially slender toward the base; body with a very limited amount of erect hair, the propodeum at most weakly hairy on the sides; posterior tibiae of female with a double row of strong serrations. Wings without a well-defined irregularity at the base of the first discoidal cell. Front and vertex unusually narrow for the genus; posterior margin of pronotum angulate; propodeum sloping smoothly, with or without rugae; apical tarsal segments of female bearing lateral spines; claws of female strongly dentate, the outer ray curved so as to be nearly parallel to the inner ray; claws of male slender, curved, deeply bifid. Females black, the antennae orange apically, the wings varying from yellowish brown to bright orange; males with a complex pattern of yellow, ferruginous, and fuscous, the wings hyaline, tinged with yellowish brown.

Key to species of argentinicus group

\section{Females}

I. Front and vertex relatively broad, upper interocular distance subequal to or slightly exceeding length of third antennal segment; ocello-ocular line slightly exceeding postocellar line argentinicus (Banks)

Front and vertex unusually narrow, upper interocular distance much shorter than third antennal segment; ocelli rather large, postocellar line exceeding ocello-ocular line

2. Wings orange, with a very narrow fuscous outer margin; at least the outer 7 antennal segments orange above longulus (Banks)

Wings translucent, lightly tinged with yellowish and with fuscous; outer five antennal segments orange above vitreus (Fox)

\section{Males}

I. Ocelli unusually large, in a compact, elevated triangle, the lateral ocelli removed from the eye margins by at most about half their own greatest diameters; mesoscutum without paired streaks, sometimes with a median pale streak; inner margin of parameres with a long, continuous series of pegs (Figs. I6, I7)

Ocelli of moderate size, the triangle not much elevated, the laterals removed from the eye margins by at least $0.8 \times$ their 
own diameters; mesoscutum with a pair of pale streaks which are often confluent behind; margin of parameres with one or two short series of pegs (Figs. I 8-20)

2. Thorax uniformly light ferruginous (mesoscutum somewhat darker); aedoeagus nearly as long as parameres, with a short, truncate apical lobe; parapenial lobes very broad, constricted subapically (Fig. I6) imitator new species

Thorax patterned with light yellowish-brown and dark brown or fuscous; aedoeagus much shorter than parameres, with a long, rounded apical lobe; parapenial lobes relatively slender (Fig. I7) longulus (Banks)

3. Propodeum strongly swollen along the median dorsal line; size large, fore wing about $15 \mathrm{~mm}$; abdomen without yellow banding; genitalia as shown in Fig. I8 ....... impensus new species

Propodeum with the slope low and smooth, not at all swollen medially; smaller and more slender species, fore wing under I $4 \mathrm{~mm}$; abdominal tergites with apical yellow bands in most specimens

4. Clypeus black, at least in part; propodeum black or with a pair of broad blackish stripes; parameres with a single set of about five pegs at the squama (Fig. 20) ................ vitreus (Fox)

Clypeus yellow; propodeum yellow, usually with a pair of narrow fuscous stripes; parameres with two sets of 3-5 pegs each (Fig. 19) argentinicus (Banks)

Chirodamus argentinicus (Banks) new combination

Amerocnemis argentinica Banks, 1946, p. 500 [Type: $\hat{\delta}$, Argentina: Tucumán (C. S. Reed) (Cornell Univ., No. 2553)].

Amerocnemis brasiliensis Banks, 1946, p. 501 [Type: $\hat{\delta}$, BRAzIL: "Barro Alto, Est. Minas", Nov. 1931 (J. Blaser) (Mus. Comp. Zool., No. 26652)]. New synonymy.

Plesiallotype.- + , argentina: Horco Molle, Tucumán, 23 Jan..-4 Feb. 1966 (C. C. Porter) [Mus. Comp. Zool.].

Description of female plesiallotype. - Length I $3 \mathrm{~mm}$; fore wing I $2.5 \mathrm{~mm}$. Body and legs black; antennae black except orange beyond segment five above, beyond segment three below; wings translucent, strongly tinged with orange except outer margins narrowly and lightly infuscated. Pubescence wholly dark, with bluish reflections on the abdomen; body sparsely setose, the propodeum with only some short, fine hair on the sides; front, vertex, mesonotum, and all coxae with a

\footnotetext{
${ }^{2} I$ have been able to find a Barro Alto in central Goias, but not in Minas
} Gerais. 
few rather long setae; apex of abdomen very strongly bristly. Clypeus $2.6 \times$ as wide as high, its apical margin weakly concave; front of moderate width, middle interocular distance $.54 \times$ width of head; upper interocular distance $.83 \times$ lower interocular, I.I $\times$ length of third antennal segment; ocello-ocular line slightly exceeding postocellar line. Postnotum very narrow and depressed at the midline; propodeum smooth, rather long, abruptly sloping on the posterior third.

Description of male type. - Length $10.5 \mathrm{~mm}$; fore wing $10 \mathrm{~mm}$. Body and appendages yellow except as follows: front with a broad central black band from antennal sockets to vertex, then extended backward to the occiput and laterally to the eye tops (but center of ocellar triangle with a small yellow spot); pronotum with a dark median streak and a pair of black chevrons on the anterior slope; mesoscutum black except for a broad median band on the posterior three-fourths, emarginate in front; scutellum black at extreme anterior and posterior margins; postnotum black medially; propodeum with paired black lines; pleura black along sutures and over much of venter of mesothorax; first abdominal segment black at extreme base, narrowly ferruginous apically; second tergite mostly ferruginous, with a narrow yellow band subapically followed by a narrow fuscous margin; tergites three and four fuscous, with a narrow transverse yellow band; remaining tergites fuscous, stained with ferruginous apically and with less distinct transverse yellow bands; sternites yellowish, with fuscous staining apically; antennae ferruginous beyond segment two, all segments infuscated above; middle and hind trochanters, sides of hind coxae, and outer part of hind femora tinged with ferruginous, hind tarsi and tips of tibiae somewhat infuscated; wings hyaline, lightly tinged with yellowish brown. Labrum well exserted, somewhat trapezoidal; clypeus $\mathrm{I} .7 \times$ as wide as high. Middle interocular distance $.55 \times$ width of head; upper interocular distance subequal to lower, $.88 \times$ middle interocular distance; ocello-ocular and postocellar lines subequal, the ocelli not notably enlarged, the posterior ocelli removed the nearest eye margin by twice their own diameter. First four antennal segments in a ratio of about $3: I: 3: 3$, third segment about half the upper interocular distance. Postnotum slightly shorter than metanotum; propodeum, in profile, sloping very weakly. Abdomen very slender basally; subgenital plate with a median basal elevation, apically rather flat; genitalia with slender parameres each bearing a series of five stout pegs at the squama and three pegs farther distad, the aedoeagus of distinctive form (Fig. I9). 
Specimens examined. -2 우, $200^{\pi} 0^{\lambda}$. ARgentina: I $0^{x}$, Tucumán [type, Cornell Univ.]; 2 우, I7 $0^{x} o^{x}$, Horco Molle, near Tucumán, Jan.-April (C. C. Porter, L. Stange, H. \& M. Townes) [Mus. Comp. Zool.; Inst. Miguel Lillo, Tucumán; and Coll. H. K. Townes]. BRAZIL: I $0^{x}$, Barro Alto [type of brasiliensis, Mus. Comp. Zool.].

Variation. - The second female is slightly larger than the plesiallotype (fore wing $14.5 \mathrm{~mm}$ ); in this specimen the middle interocular distance is $.52 \times$ the head width, the upper interocular distance $\mathrm{I} .03$ $X$ the length of the third antennal segment. Otherwise there are no noteworthy differences from the plesiallotype.

The males vary only slightly in size (fore wing 9-1 $3 \mathrm{~mm}$ ) but show considerable variation in the details of the color pattern. Most of the I 7 males from Horco Molle resemble the type closely, but in several the second tergite is mostly blackish instead of ferruginous, and in several the major part of the first tergite is ferruginous rather than yellow. These darker males approach rather closely the type of brasiliensis, which has the abdominal dorsum mostly fuscous except for prominent transverse pale bands toward the apex of each tergite. This specimen also has some black on the coxae and wider dark bands on the propodeum. The genitalia of the types of argentinicus and brasiliensis are virtually identical.

\section{Chirodamus vitreus (Fox) new combination}

Salius (Priocnemis) vitreus Fox, 1897, p. 274 [Type: + , BRAzlL: Rio de Janeiro, November (? location of type)].

Calopompilus vitreus: Banks, 1946, p. 490 ( $ᄋ$, Brit. Guiana, Surinam, Brazil).

Batozonus pentodon Arlé, 1947, p. 425-426, figs. 17-22 [Type: $\hat{\delta}$, BRAZIL: Niteró, Rio de Janeiro, 17 Aug. 1947 (R. Arlé) (Arlé Collection)]. New synonymy.

Plesiotype. - + , BRazIL: Rio de Janeiro, 7 March 1966 (H. and M. Townes) [Coll. H. K. Townes].

Description of female plesiotype. - Length $20 \mathrm{~mm}$; fore wing 17.5 mm. Body black; legs black, fading to dark castaneous apically; antennae black, orange beyond segment seven above, beyond segment three below; wings translucent, vitreous, tinged with yellowish-brown except lightly tinged with fuscous along outer margin. Pubescence fine, with weak bluish reflections, somewhat cinereous on the coxae and lower front; clypeus, front, vertex, thoracic dorsum, coxae, and front femora each with a few strong setae; propodeum with numerous fine setae on the sides; abdomen with strong setae below, the apex 
densely setose above and below. Clypeus $2.5 \times$ as wide as high, its apical margin weakly concave; front and vertex unusually narrow, middle interocular distance $.48 \times$ width of head, $.93 \times$ lower interocular distance; upper interocular distance only $.67 \times$ lower interocular, $.80 \times$ length of third antennal segment; postocellar line much exceeding ocello-ocular line, the latter less than the diameter of a posterior ocellus. Pronotum very broadly angulate behind; postnotum very narrow dorsally; propodeum with an impressed median line, the slope weakly transversely rugose.

Plesiallotype. - $\hat{o}$, BRAZIL: same data as plesiotype except collected 6 March I966 [Coll. H. K. Townes].

Description of male plesiallotype. - Length $\mathrm{I} 2 \mathrm{~mm}$; fore wing I I $\mathrm{mm}$. Body yelow, marked with black as follows: spot in center of clypeus; center of front from antennal sockets to vertex, then laterally to eye tops and back to cover much of occiput (but with yellow blotching in and beside ocellar triangle); greater part of pronotal slope; mesoscutum except paired yellow lines on posterior two-thirds; all but paired lateral spots on scutellum; posterior margin of metanotum and much of postnotum; very broad longitudinal stripes on propodeum, confluent at extreme base and only narrowly separated over much of slope; mesopleura with large lateral and ventral blotches, and metapleura with two blotches; abdomen mostly blackish, but each tergite with a narrow, transverse, subapical yellow band, and the sternites somewhat more broadly banded with yellow; antennal scape yellow, blotched with black above, following segment all black, remainder of antenna ferruginous below, fuscous above; front coxae yellow, other coxae streaked with yellow and black; trochanters yellow, remainder of legs streaked with yellow and brown; wings hyaline, lightly tinged with yellowish brown. Labrum weakly exserted; clypeus I.8 $\times$ as wide as high. Middle interocular distance $.52 \times$ width of head; upper interocular distance $.93 \times$ lower, $.82 \times$ middle interocular distance; postocellar line much exceeding ocello-ocular line, the latter slightly less than the diameter of a posterior ocellus. Third antennal segment equal to about 6 upper interocular distance. Postnotum, at the midline, less than a third the length of the metanotum; slope of propodeum very low and even. Abdomen very slender basally; subgenital plate flat, with a weak median basal elevation; parameres with a single series of five stout spines at the squama, the aedoeagus slightly differently shaped than in argentinicus (Fig. 20; see also Arlé, 1947, figs. 17-22, showing the parameres in lateral view, the genitalia in dorsal view, etc.). 
Specimens examined -4 우, I3 $0^{\pi} \sigma^{\pi}$. BRITISH GUIANA: I + , Kartabo, 30 Oct. I920 (W. M. Wheeler) [Mus. Comp. Zool.]. BRAZIL: i + , Belem, Pará, May r924 (F. X. Williams) [Mus. Comp. Zool.]; 2 우, $4 \sigma^{\pi} \sigma^{\pi}$, Rio de Janeiro, Nov., March [Carn. Mus., H. K. Townes]; I $\sigma^{x}$, Itatlaya, Rio de Janeiro, Dec. I928 (J. Zikán) [Mus. Comp. Zool.]; $20^{\pi} o^{x}$, Quatro Barros, near Curitiba, Parana, 6 Feb. I966 (H. \& M. Townes) [H. K. Townes]; $20^{\top} o^{\star}$, Campina Grande, near Curitiba, Feb. 1966 (H. \& M. Townes) [H. K. Townes]; I $0^{*}$, Teresópolis, Santa Catarina, I2 March 1966 (H. \& M. Townes) [H. K. Townes]; $30^{x} o^{x}$, Alto da Serra, Morretes, Parana, I2 Feb. I966 (H. \& M. Townes) [H. K. Townes].

Variation. - The females vary only slightly in size (fore wing I5-I7.5 mm). The two from British Guiana and Pará have the wings distinctly more yellowish than those from Rio de Janeiro; the British Guiana specimen has scarcely any evidence of rugae on the propodeum. Otherwise the four specimens are very similar.

The males show some variation in size (fore wing II-I4 mm) and much variation in color. One of the males from Alto da Serra is less extensively marked with black than the plesiallotype (e.g., the stripes on the propodeum are more widely separated and the mesopleura little marked with black), but the majority are considerably darker. The specimens from Campina Grande and Teresópolis have the clypeus wholly black, the thorax and propodeum almost wholly black, and the abdomen black except for narrow and sometimes evanescent transverse yellow bands; the middle and hind coxae are also mostly black and the legs generally rather dark. Most specimens are intermediate between the two extremes. The males from Campina Grande and Quatro Barros have the ocelli smaller than any others, the postocellar line exceeding the ocello-ocular line only slightly, the latter being somewhat greater than the diameter of a posterior ocellus. The genitalia of six males of differing coloration and different ocellar size were studied and found to be identical.

Remarks. - I have seen the types of neither vitreus nor pentodon. The type of the former is not with the other Fox types at the Carnegie Museum, and my interpretation of the species is based on specimens determined by Banks and agreeing well with Fox's description. The males which I assign to this species agree very well indeed with Arlés description of pentodon and with his excellent illustrations. Arlé noted that the genitalia differed greatly from other "Batozonus" (=Poecilopompilus), not realizing that his specimen belonged to a different subfamily. 
Chirodamus longulus (Banks) new combination

Amerocnemis longula Banks, 1946, p. 502 [Type: $\hat{\sigma}$, BRAzIL: Hyutanahan, Rio Purus, March (S. M. Klages) (Carnegie Mus.; topotypic paratype in Mus. Comp. Zool.)].

Plesiallotype. - + , PERU: Quincemil, Dept. Cusco, 750 meters, Aug. 1962 (L. Peña) [Mus. Comp. Zool.].

Description of female plesiallotype. - Length $24 \mathrm{~mm}$; fore wing I $7.5 \mathrm{~mm}$. Body and legs black, clothed with a very fine, mostly cinereous pubescence; antennae black, orange beyond segment four above, beyond the middle of the third segment below; wings translucent, strongly tinged with orange, except fuscous at extreme base, through most of costal cell, and narrowly along outer margin. Clypeus, front, vertex, thoracic dorsum, coxae, and front femora each with a few strong setae; abdomen densely setose apically; propodeum with many fine but fairly long setae on the sides of the slope. Clypeus $2.4 \times$ as wide as high, its apical margin slightly concave; front and vertex very narrow, middle interocular distance .48 $\times$ width of head, $.90 \times$ lower interocular distance; upper interocular distance only .62 lower, $.70 \times$ length of third antennal segment; postocellar line $\mathrm{I} .4 \times$ ocello-ocular line, the latter only two-thirds the maximum diameter of a posterior ocellus. Postnotum constricted on the midline; propodeum sloping evenly, with some very weak transverse rugae, the median line weakly impressed.

Description of male topotypic paratype. - Length $19 \mathrm{~mm}$; fore wing $15 \mathrm{~mm}$. Body in large part yellow and light ferruginous, with limited fuscous markings; head mostly yellow, but center of upper front, vertex, and occiput light ferruginous (yellow streaks behind ocelli not quite connected to yellow outer orbits); pronotum bordered with yellow on all sides, the slope ferruginous, slightly infuscated; mesoscutum fuscous, with a median yellow streak and yellow lateral streaks, just above the tegulae; scutellum fusco-ferruginous, with large yellow spots; metanotum mostly yellow, postnotum ferruginous with small yellow spots; propodeum yellow, with a large basal ferruginous area which extends back on each side to the posterior angles; pleura yellow, stained with ferruginous along the sutures and ventrally; abdomen light ferruginous, each tergite with a weak apical fuscous band (less distinct caudad); antennae mostly light ferruginous, segments 4-6 and 9-I3 fuscous above; legs mostly light ferruginous, but the front coxae yellow, the other coxae streaked with yellow; wings hyaline, very lightly tinged with brown. Labrum strongly exserted; clypeus $1.7 \times$ as wide as high. Front and vertex very narrow, middle interocular distance $.45 \times$ width of head; upper 
interocular distance $.92 \times$ lower, $.80 \times$ middle interocular distance; postocellar line more than twice the ocello-ocular line, the latter only about a third the maximum diameter of a posterior ocellus. First four antennal segments in a ratio of about $18: 5: 23: 22$, segment three equal to $.92 \times$ the upper interocular distance. Postnotum nearly as long as metanotum, though much shorter at the midline, where it is constricted; slope of propodeum very low and even. Abdomen long and slender; subgenital plate flat, with strong marginal bristles; genitalia with the parameres broad, bearing a partially double row of slender, blunt spines, the aedoeagus of characteristic shape (Fig. I7).

Specimens examined. - 5 우, I9 $\sigma^{\top} \sigma^{\top}$. BRAzIL: I $\sigma^{\top}$, Hyutanahan, Rio Purus, Amazonas, March [paratype, Mus. Comp. Zool.] ; i ㅇ, Peru-Brazil Frontier, 2I Jan. I928 (H. Bassler) [Mus. Comp. Zool.]. PERU: 4 Oᄋ, I $3 \sigma^{\star} \sigma^{\star}$, Quincemil, Dept. Cusco, 750 meters, Aug.-Oct. 1962 (L. Peña) [Mus. Comp. Zool., Coll. H. K. Townes]; $2 \sigma^{\top} \sigma^{\top}$, Avispas, Madre de Dios, 400 meters, Sept.-Oct. 1962 (L. Peña) [Mus. Comp. Zool.] ; $2 \sigma^{\pi} \sigma^{\pi}$, Paucartambo, Dept. Cusco, 400 meters, March r952 (F. Woytkowski) [H. K. Townes]. Bolivia: i $\sigma^{\star}$, Prov. Sara [=Santa Cruz], 450 meters, (J. Steinbach) [Carnegie Mus.].

Variation. - The five females exhibit little variation in size, color, or standard measurements (fore wing $17-20 \mathrm{~mm}$ ). In the specimen from the Peru-Brazil border, the ocelli are even larger than described above, the postocellar line being I. $8 \times$ the ocello-ocular line, the latter only about half the diameter of a lateral ocellus; in this specimen the upper interocular distance is only $.65 \times$ the length of the third antennal segment.

In contrast, the males exhibit much variation in size and color. In the Quincemil series, the smallest male has a fore wing length of only $9.5 \mathrm{~mm}$, the largest $15.5 \mathrm{~mm}$. None of the other males are smaller, but one from Paucartambo, Peru is larger: fore wing I7 $\mathrm{mm}$. In several specimens the dorsal areas described as light ferruginous in the paratype are more or less tinged with fuscous, although in many cases the pleura and legs are more extensively yellow than in the paratype. The abdominal banding is especially variable; in several specimens there are narrow bands of yellow at the base of the second (and sometimes the third) tergite in addition to the usual fuscous apical bands on a ferruginous background; in one of the Paucartambo males and especially in the one from Bolivia, the banding is largely obscured by a light fuscous coloration except on the 
basal two segments. There is considerable variation in the width of the front (middle interocular distance $.43-.53 \times$ width of head) and in the size of the ocelli (postocellar line I.6-2.3 $\times$ ocello-ocular line, the latter $.25-.55 \times$ the diameter of a lateral ocellus). I examined the genitalia of four males from as many localities and found no variation worthy of note.

\section{Chirodamus imitator new species}

Holotype. - $0^{x}$, ECUADOR: Libertad, $2 \mathrm{~km}$. SE Ongota [near Tena], I2 May I963 (L. Peña) [Mus. Comp. Zool., No. 31598].

Description of male type. - Length $22 \mathrm{~mm}$; fore wing $17.5 \mathrm{~mm}$. Body and legs rather uniformly light castaneous except as follows: tips of mandibles black; scape yellowish beneath, flagellum fuscous on upper surface (antennae missing beyond segment five) ; clypeus, face, broad inner orbits, and rather narrow outer orbits yellow; pronotum slightly suffused with yellow on sides and along posterior margin; mesoscutum and scutellum uniformly dark castaneous; metanotum suffused with yellow; abdominal tergites with rather weak, fuscous apical bands; hind tibial spurs and hind tarsi somewhat infuscated; pterostigma light castaneous, wing membranes wholly, lightly suffused with yellowish-brown. Temples and propleura with numerous pale setae; front coxae, vertex, and sides of propodeum with some pale, thin setae; abdominal venter with numerous short, suberect, pale setae. Labrum exserted to about half the length of the clypeus, its apical margin slightly notched. Clypeus I.6 $\times$ as wide as high, its apical margin truncate. Head I.I $\times$ as wide as high; front very narrow, middle interocular distance only $.43 \times$ width of head; upper interocular distance $.82 \times$ lower interocular distance; eyes and ocelli unusually large and convex; diameter of front ocellus one third the middle interocular distance; laterals removed from eye margins by only one fourth their own greatest diameter; postocellar line 1.5 $X$ ocello-ocular line; area within ocellar triangle considerably elevated. First four antennal segments in a ratio of about 19:5:30:27, third segment $4.5 X$ as long as its apical width, I.25 $X$ as long as upper interocular distance. Pronotum rather small, not at all swollen on the sides, its posterior margin strongly angulate; postnotum approximately as long as metanotum although considerably shortened at the midline; propodeum sloping very smoothly and gradually, the median line not impressed. Hind wing with the anal vein sloping up gradually to meet media slightly beyond origin of cubital vein; transverse median vein of fore wing strongly oblique, meeting media 
far beyond origin of basal vein; second submarginal cell $2.4 \times$ as wide as high, receiving first recurrent vein two-thirds the distance from base; third submarginal cell twice as wide as its maximum height, receiving second recurrent vein .4 distance from base. Abdomen very slender, the first segment especially so; subgenital plate spatulate, rather blunt apically, with a few strong lateral setae; genitalia with double basal hooklets and with strong pegs on the parameres, but otherwise with quite differently shaped volsellae, parapenial lobes, and aedoeagus from other members of this complex (Fig. I6).

\section{Chirodamus impensus new species}

Holotype. - ox, Paraguay: C. Pfannel, Guaira, Dec. I950 (Foerster) [Mus. Comp. Zool., No. 31599].

Description of male type. - Length I7 $\mathrm{mm}$; fore wing $15 \mathrm{~mm}$. Coloration pale, patterned with yellow, light ferruginous, and black (it is possible that the light ferruginous represents discoloration from cyanide) ; head mostly light ferruginous, tips of mandibles black, central part of front above antennae and a band between eye tops black, upper surface of flagellum slightly infuscated; pronotum yellow, tinged with rufous above; mesoscutum fuscous, with a pair of yellow discal lines which fuse behind; scutellum yellow, with some basal and apical black connected by a thin, black median streak; metanotum, postnotum, and propodeum yellow; pleura yellow, suffused with rufous on the upper half; coxae yellow, legs otherwise light ferruginous; abdomen ferruginous over basal three segments, remainder fuscous; pterostigma brown, wing membranes lightly tinged with yellowish brown. Temples and propleura with numerous pale setae; propodeum with a few weak setae on the extreme sides; abdominal venter with numerous very short setae. Labrum slightly exserted, truncate; clypeus $\mathrm{I} .85 \times$ as wide as high, truncate apically. Head I.09 $X$ as wide as high; front of moderate width, middle interocular distance $.54 \times$ width of head; upper interocular distance .90 $\times$ lower interocular distance; ocelli not greatly enlarged nor ocellar triangle notably elevated; lateral ocelli removed from eye margins by $\mathrm{I} .35 \times$ their own greatest diameter; ocello-ocular line very slightly exceeding postocellar line. First four antennal segments in a ratio of about 19:5:19:18, third segment $2.5 \times$ as long as its apical width, o.6 $\times$ as long as upper interocular distance. Thoracic features as in imitator, but the propodeum decidedly gibbous along the median area, especially toward the base. Wing venation as described for imitator 
except as follows: first recurrent vein received at middle of second submarginal cell, second recurrent .43 distance from base of third submarginal, the latter cell $\mathrm{I} .5 \times$ as wide as its greatest height. Abdomen much more robust than in imitator, the first segment more strongly expanded from base to apex; subgenital plate tapered toward the apex, which is subtruncate; genitalia as shown in Fig. I8.

\section{ACKNOWLEDGEMENTS}

I wish to thank Charles C. Porter for supplying the material which inspired this paper and for providing me with notes regarding his collecting experiences with members of this complex. He also identified the Ichneumonidae. Henry K. Townes and Lincoln P. Brower read an earlier draft of the paper and made a number of useful suggestions. Mary Jane West suggested several improvements in the final draft.

ARLÉ, R.

\section{REFERENCES}

1947. Nouvelles espèces de Pompilidae du Brésil (Hymenoptera). Revista Ent., 18: 416-428.

BANKS, N.

1945. The Psammocharidae (Spider-Wasps) of Northern South America. Bol. Ent. Venez., 4: 81-126.

1946. Studies of South American Psammocharidae. Part I. Bull. Mus. Comp. Zool. Harvard, 96: 311-525.

Brower, J. V. Z., and L. P. Brower

1965. Experimental studies of mimicry. 8. Further investigations of honeybees (Apis mellifera) and their dronefly mimics (Eristalis spp.). Amer. Nat., 99: 173-188.

Brower, L. P., J. V. Z. Brower, and J. M. Corvino

1967. Plant poisons in a terrestrial food chain. Proc. Nat. Acad. Sci., 57: 893-898.

Evans, H. E.

1966. A revision of the Mexican and Central American spider wasps of the subfamily Pompilinae (Hymenoptera: Pompilidae). Mem.

Fox, W. J. Amer. Ent. Soc., no. 20. 442 pp.

1897. Contributions to a knowledge of the Hymenoptera of Brazil. Proc. Acad. Nat. Sci. Phila., 1897, pp. 229-283.

TOWNES, H. K.

1957. Nearctic wasps of the subfamilies Pepsinae and Ceropalinae. Bull. U. S. Nat. Mus., 209: 1-286. 

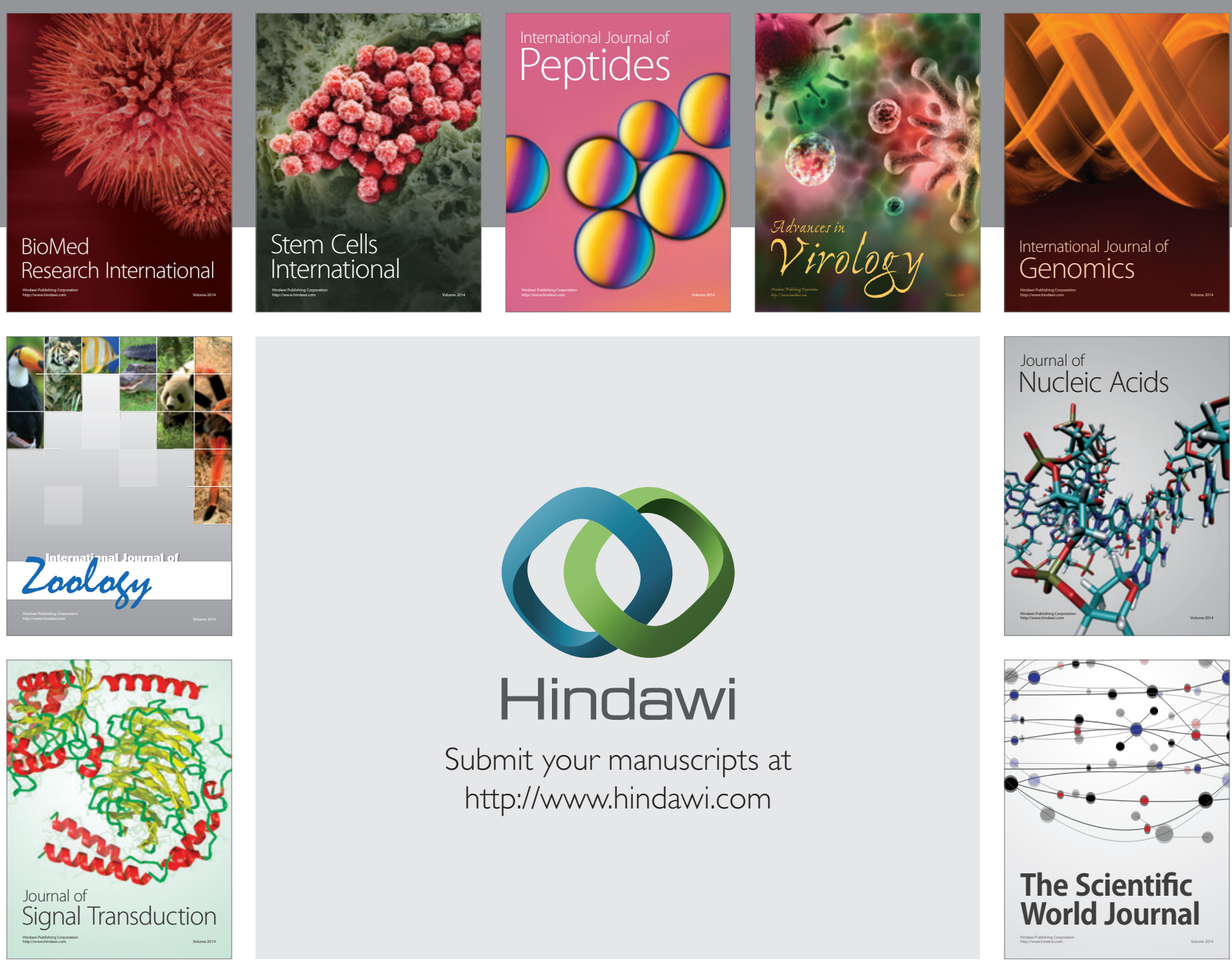

Submit your manuscripts at

http://www.hindawi.com
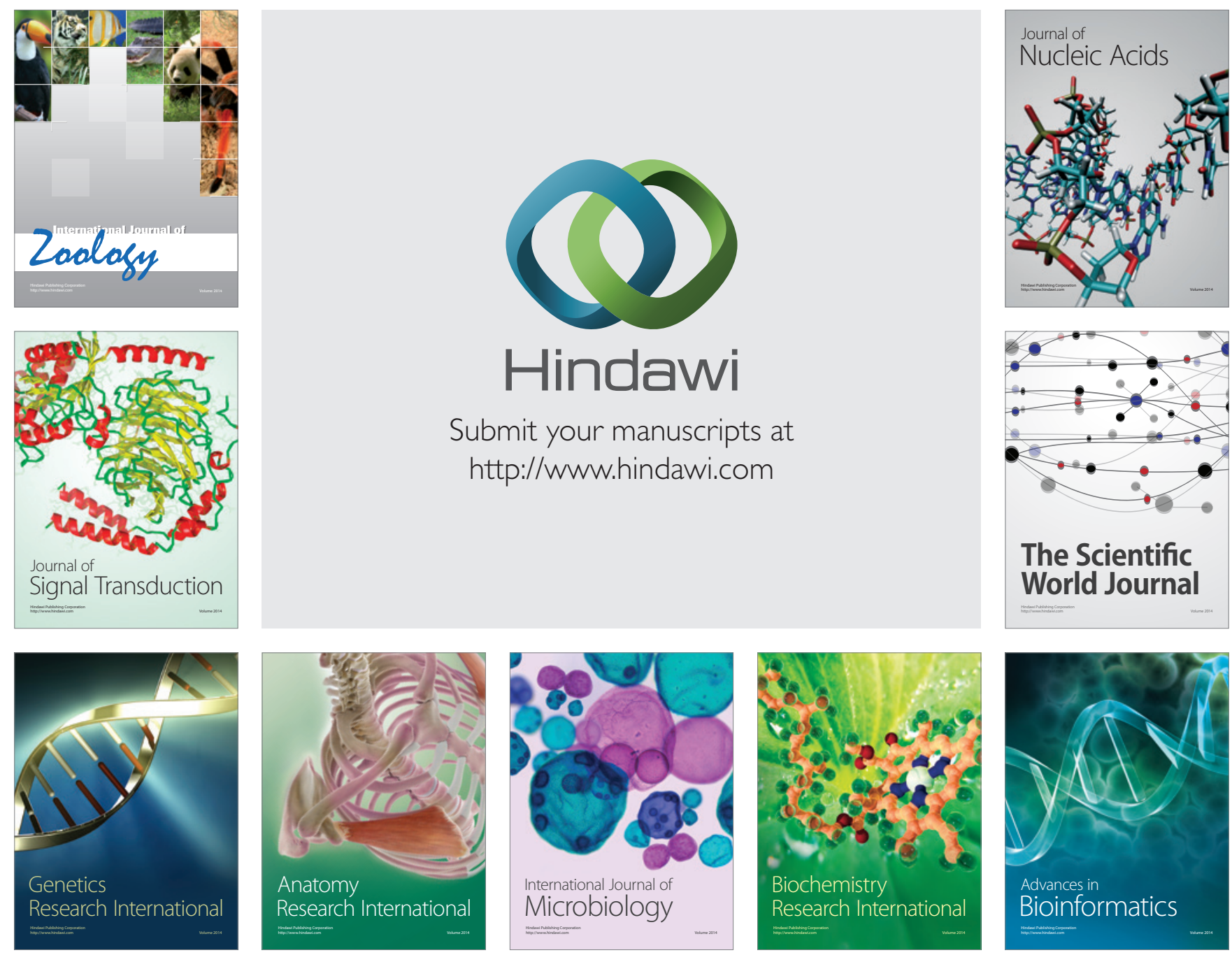

The Scientific World Journal
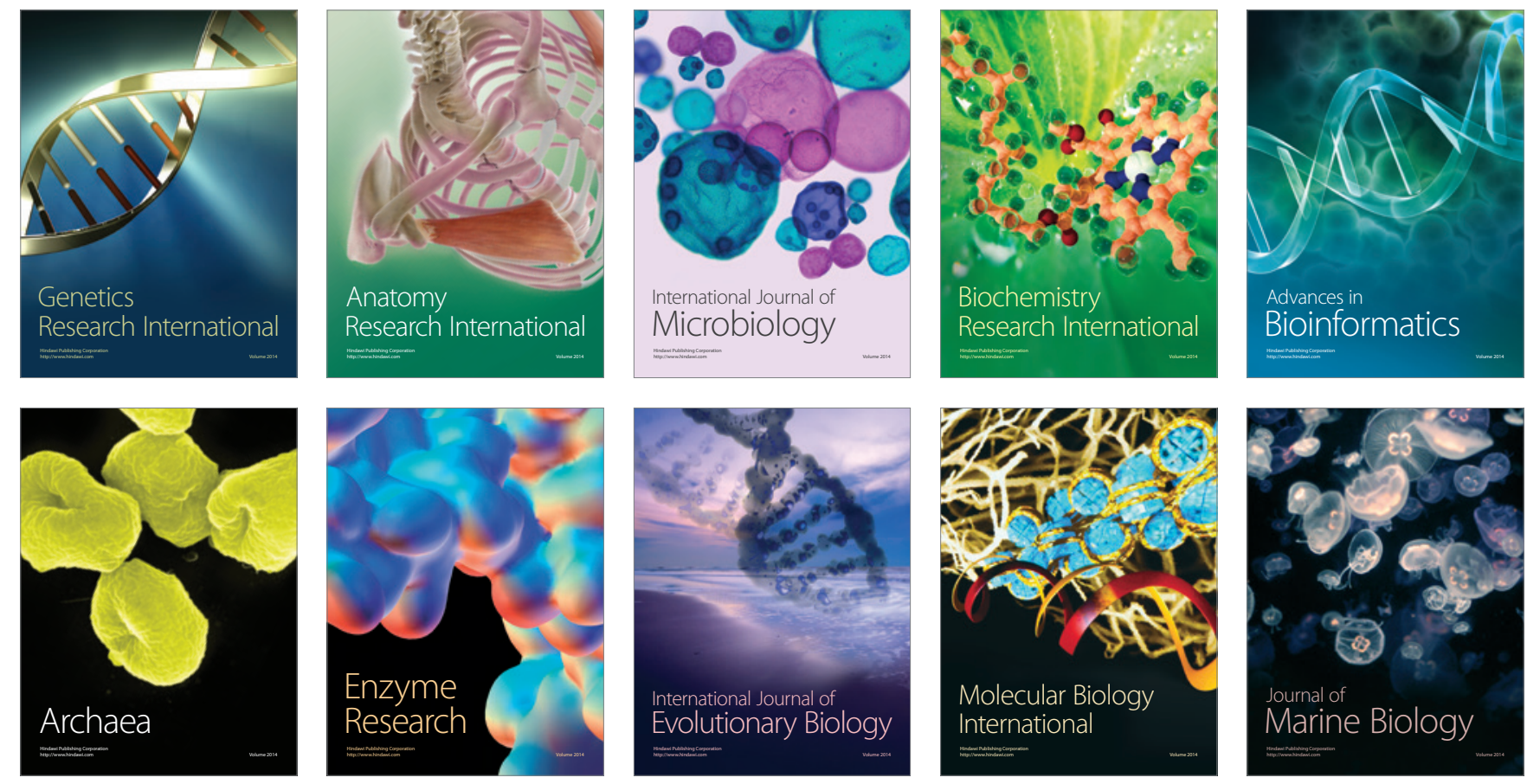